\title{
Pertumbuhan Rumput Laut Gracilaria sp. pada Media yang Mengandung Tembaga (Cu) dengan Konsentrasi yang Berbeda
}

\author{
Endang Supriyantini, Gunawan Widi Santosa, Ladies Nikita Alamanda* \\ Departemen Ilmu Kelautan, Fakultas Perikanan dan Ilmu Kelautan, Universitas Diponegoro \\ Jl. Prof. Sudarto, SH, Tembalang, Semarang, Jawa Tengah, 50275 \\ Email: ladiesnikitaa@gmail.com
}

\begin{abstract}
Abstrak
Budidaya rumput laut banyak dilakukan untuk memenuhi dan meningkatkan produksinya, namun masih banyak kendala, sehingga hasil produksinyabelum stabil. Hal ini dapat dilihat dengan pemberian nutrien yang diharapkan akan meningkatkan pertumbuhannya. Tujuan dari penelitianuntuk mengetahui pertumbuhan dan kemampuan absorpsi Gracilaria sp. pada media yang mengandung $\mathrm{Cu}$ dengan konsentrasi yang berbeda. Metode yang digunakan adalah metode eksperimental laboratoris dengan Rancangan Acak Lengkap (RAL).Perlakuan penambahan konsentrasi $\mathrm{Cu}$ pada media pemeliharaan yang terdiri dari 4 tingkat yaitu kontrol (0,036 ppm, sesuai dengan konsentrasi $\mathrm{Cu}$ pada air laut), $0.5 \mathrm{ppm}, 5 \mathrm{ppm}$, dan50 ppm dengan 3 pengulangan. Hasil memperlihatkan bahwa penambahan $\mathrm{Cu}$ dengan konsentrasi yang berbeda memiliki pengaruh nyata $(\mathrm{p}<0,05)$ terhadap pertumbuhan dan kemampuan absorpsi pada Gracilaria sp. Pertumbuhan Gracilaria sp. tertinggi dicapai pada perlakuan A (kontrol) dengan pertambahan berat sebesar 25,34 g dan laju petumbuhan spesifik (SGR) sebesar $0,43 \%$. Nilai pertumbuhan mutlak dan laju pertumbuhan spesifik (SGR) yang didapatkan pada perlakuan B (0,5 ppm) sebesar $-80,37 \mathrm{~g}$ dan $-1,84 \%$ per hari, perlakuan C (5 ppm) sebesar $-85,19 \mathrm{~g}$ dan $-2,02 \%$ per hari, dan perlakuan D (50 ppm) sebesar $-99,19 \mathrm{~g}$ dan $-2,47 \%$ per hari. Semakin tinggi konsentrasi $\mathrm{Cu}$ yang diberikan maka pertumbuhan Gracilaria sp. akan semakin rendah.
\end{abstract}

Kata kunci: Gracilaria sp., Pertumbuhan, Tembaga $(\mathrm{Cu})$.

\section{Abstract \\ Seaweed Gracilaria sp. Growth in Copper (Cu) Media With Different Concentration}

Seaweed cultivation is done to meet and improve its production, but there are still many obstacles, so its results are not yet stable. This can be seen with the awarding of the nutrients that will hopefully increase its growth. The goal of the research is to know the growth and absorption ability of Gracilaria SP. in medium containing different concentrations of $\mathrm{Cu}$ with. The method used is the method of experimental design of randomized Complete laboratories $(R A L)$. Addition of $C u$ concentration on treatment of media maintenance which consists of 4 levels, namely control ( $0.036 \mathrm{ppm}$, according to the concentration of $\mathrm{Cu}$ in sea water), $0.5 \mathrm{ppm}, 5 \mathrm{ppm}$ and $50 \mathrm{ppm}$, with three repetitions. The results showed that the addition of $\mathrm{Cu}$ with a different concentration of real influence $(p<0.05)$ towards growth and the ability of absorption on Gracilaria sp. Highest growth of Gracilaria sp. was achieved on A treatment (control) and the increase of the weight of $25.34 \mathrm{~g}$ and specific growth rate (SGR) of $0.43 \%$. The absolute growth rate and specific growth rate $(S G R)$ obtained at the treatment $B(0.5 \mathrm{ppm})$ of $-80.37 \mathrm{~g}$ and $-1.84 \%$ per day, treatment $C$ (5 ppm) of $-85.19 \mathrm{~g}$ and $-2.02 \%$ per day, and treatment $\mathrm{D}(50 \mathrm{ppm})$ for $-99.19 \mathrm{~g}$ and $-2.47 \%$ per day. The higher the concentration of $\mathrm{Cu}$ given, then the growth of Gracilaria sp. will be even lower.

Keywords: Gracilaria sp., Growth, Copper $(\mathrm{Cu})$.

\section{PENDAHULUAN}

Rumput laut atau seaweed merupakan salah satu tumbuhan laut yang tergolong dalam makroalga benthik atau benthic algae yang hidupnya melekat di dasar perairan. Tanaman ini tidak bisa dibedakan antara bagian akar, batang, dan daun, sehingga bagian tumbuhan tersebut disebut thallus, oleh karena itu tergolong tumbuhan tingkat rendah (Anggadiredja et al., 2008).

Berdasarkan kandungan pigmennya, rumput laut dikelompokkan menjadi 3 kelas yaitu rumput

\footnotetext{
*Corresponding author

http://ejournal.undip.ac.id/index.php/buloma

Diterima/Received : 01-12-2017

buloma.undip@gmail.com

Disetujui/Accepted : 23-01-2018
} 
laut merah (Rhodophyceae), rumput laut coklat (Phaeophyceae), dan rumput laut hijau (Chlorophyceae). Ketiga golongan tersebut mempunyai nilai ekonomi yang cukup tinggi karena dapat menghasilkan metabolit primer senyawa hidrokoloid seperti agar, karagenan, dan alginat (Anggadiredja et al., 2008).

Salah satu contoh spesies yang bernilai ekonomis di Indonesia adalah Gracilaria sp. dari kelas Rhodophyceae. Rumput laut ini banyak digunakan sebagaibahan baku pembuatan agaragar. Agar berfungsi sebagai bahan pengental (thickener), stabilisator (stabilizer), dan pengemulsi (emulsifiying agent). Dalam industri farmasi, agar-agar berguna sebagai pencahar atau peluntur dan kultur bakteri. Industri kosmetika, agar-agar digunakan dalam pembuatan salep, cream, sabun dan pembersih muka atau lotion. Industri lain menggunakan agar-agar sebagai bahan additive atau tambahan, misalnya dalam beberapa proses pada industri kertas, tekstil, fotografi, semir sepatu, tapal gigi, odol, pengalengan ikan atau daging dan juga untuk kepentingan mikrotomi, museum dan kriminologi (Ma'ruf et al., 2014).

Permintaan dunia akan agar-agar terus meningkat setiap tahunnya. Permintaan yang cenderung meningkat menyebabkan kebutuhan juga semakin besar, sehingga ketersediaan Gracilaria sp. di alam menjadi sangat terbatas. Kebutuhan Gracilaria sp. untuk industri agar-agar di dalam negeri dan ekspor mencapai 27.000 ton per tahun. Sementara, produksi rumput laut untuk jenis tersebut hanya mencapai 16.000 ton/ tahun sehingga kekurangan (Anggadiredja et al., 2006).

Peningkatan produksi Gracilaria sp. dapat ditempuh melalui usaha budidaya.Budidaya rumput laut merupakan salah satu cara yang dapat memenuhi permintaan industri dan juga menekan pengambilan di alam secara berlebihan (Budiyani et al., 2012). Untuk mencapai produksi yang maksimal, Gracilaria sp. perlu dipacu dengan pemberian nutrien yang diharapkan akan meningkatkan pertumbuhannya.

Berdasarkan tingkat kebutuhannya, nutrien yang diperlukan oleh rumput laut dibagi menjadi dua jenis yaitu makronutrien dan mikronutrien. Makronutrien adalah nutrien yang dibutuhkan tanaman dalam jumlah yang banyak seperti N, P, dan $\mathrm{K}$ sedangkan mikronutrien adalah nutrien yang dibutuhkan tanaman dalam jumlah yang sedikit tetapi apabila jumlahnya berlebihan akan menimbulkan efek toksik seperti Fe, Mn, B, Mo, $\mathrm{Cu}, \mathrm{Zn}$ dan $\mathrm{Cl}$ (Sitompul, 2015).
Salah satu nutrien yang diperlukan oleh rumput laut untuk pertumbuhannya adalah tembaga $(\mathrm{Cu}) . \mathrm{Cu}$ merupakan mikronutrien yang esensial bagi tanaman karena walaupun diperlukan dalam jumlah relatif sedikit tetapi sangat besar peranannya. $\mathrm{Cu}$ berfungsi sebagai penyusun enzim, pembentukan klorofil, serta metabolisme karbohidrat dan protein dalam proses pertumbuhan rumput laut (Hardjowigeno, 2003). Keberadaan $\mathrm{Cu}$ yang berlebih akan menimbulkan efek toksik pada tanaman. Toksisitas yang dimiliki $\mathrm{Cu}$ akan bekerja apabila masuk ke dalam tubuh organisme dalam jumlah yang besar atau melebihi nilai toleransi organisme tersebut (Yulianto et al., 2006). Oleh karena itu, dengan penambahan $\mathrm{Cu}$ pada konsentrasi yang berbeda diharapkan dapat mengetahui konsentrasi yang tepat dalam penambahan nutrien $\mathrm{Cu}$ sehingga Gracilaria sp. dapat tumbuh secara optimal.

Penelitian ini bertujuan untuk mengetahui pertumbuhan dan kemampuan absorpsi Gracilaria sp. pada media yang mengandung $\mathrm{Cu}$ dengan konsentrasi yang berbeda.

\section{MATERI DAN METODE}

Materi yang digunakan dalam penelitian ini adalah bibit Gracilaria sp. berumur 30 hari yang berasal dari budidaya rumput laut di Balai Besar Perikanan Budidaya Air Payau (BBPBAP) Jepara. Menurut Akmal et al. (2008), rumput laut yang digunakan sebagai bibit dapat dipanen pada umur 25 hingga 30 hari dikarenakan pada umur tersebut pertumbuhan rumput laut secara vegetatif dapat tumbuh secara maksimal, sehingga sangat cocok digunakan sebagai bibit. Gracilaria $\mathrm{sp}$. diaklimatisasi selama 7 hari agar dapat beradaptasi dengan lingkungan yang baru. Masing-masing akuarium membutuhkan Gracilaria sp. sebanyak \pm 400 g, kemudian rumput laut tersebut dibagi menjadi dua ikatan yaitu $200 \mathrm{~g}$ untuk pengukuran pertumbuhan dan $200 \mathrm{~g}$ untuk sampel yang akan dianalisis absorpsinya terhadap konsentrasi $\mathrm{Cu}$. Sebelum rumput laut digunakan, dilakukan pengukuran konsentrasi $\mathrm{Cu}$ yang terdapat di dalam Gracilaria sp. yaitu sebesar 0,67 ppm.

Wadah uji yang digunakan dalam penelitian ini adalah akuarium berbahan kaca bening berukuran $50 \mathrm{~cm} \times 30 \mathrm{~cm} \times 35 \mathrm{~cm}$ dengan ketebalan $0,5 \mathrm{~cm}$ sebanyak 12 buah. Masingmasing akuarium dilengkapi dengan aerasi yang ditempatkan pada bagian tengah akuarium agar terjadi difusi udara, sehingga oksigen dapat masuk dalam air (Prihartono et al., 2010). Media pemeliharaan yang digunakan dalam penelitian ini 
adalah air laut hasil filtrasi dari BBPBAP Jepara. Satu akuarium diisi air laut sebanyak $30 \mathrm{~L}$ dengan salinitas 25 ppt. Sebelum media pemeliharaan digunakan, dilakukan pengukuran konsentrasi $\mathrm{Cu}$ yang terdapat di dalam media pemeliharaan yaitu sebesar 0,04 ppm. Media pemeliharaan ditambah dengan unsur $\mathrm{Cu}$ yang berasal dari tembaga (II) sulfat pentahidrat $\left(\mathrm{CuSO}_{4} .5 \mathrm{H}_{2} \mathrm{O}\right)$. Pengenceran dapat dihitung dengan rumus sebagai berikut :

Keterangan :

$$
\mathrm{V}_{1} \mathrm{xN}_{1}=\mathrm{V}_{2} \mathrm{xN}_{2}
$$

$\mathrm{V} 1=$ Volume larutan stok $(\mathrm{L})$

N1 = Konsentrasi larutan stok (ppm)

$\mathrm{V} 2$ = Volume larutan uji perlakuan (L)

$\mathrm{N} 2$ = Konsentrasi perlakuan $(\mathrm{ppm})$

Metode penelitian yang digunakan adalah metode eksperimental laboratoris dengan rancangan percobaan adalah rancangan acak lengkap (RAL). Pada penelitian ini diterapkan 3 perlakuan dan 1 kontrol pada tanaman uji, dimana masing-masing perlakuan dan kontrol diulang 3 kali. Penambahan konsentrasi $\mathrm{Cu}$ yang akan diterapkan, yaitu : $\mathrm{A}=$ Kontrol, $\mathrm{B}=$ konsentrasi $\mathrm{Cu}$ 0,5 ppm, $\mathrm{C}=$ konsentrasi $\mathrm{Cu} 5 \mathrm{ppm}, \mathrm{D}=$ konsentrasi $\mathrm{Cu} 50 \mathrm{ppm}$. Sumber cahaya menggunakan lampu TL 40 watt yang setara dengan 3500 - 4000 lux (Alamsjah et al., 2008). Pengaturan waktu pencahayaan disesuaikan dengan kondisi di alam yaitu : 12 jam terang dan 12 jam gelap.

Pengukuran parameter penelitian, berupa: pengukuran pertumbuhan rumput laut (berat) dilakukan setiap minggu sekali selama 28 hari masa penelitian, pengukuran kualitas air media pemeliharaan (suhu, salinitas, $\mathrm{pH}$ ) selama 28 hari masa penelitian, pengamatan visual pada Gracilaria sp. setiap minggu sekali selama 28 hari masa penelitian, dan pengukuran konsentrasi $\mathrm{Cu}$ pada Gracilaria sp. dan media pemeliharaan dilakukan setiap minggu sekali selama 28 hari masa penelitian. Analisis konsentrasi $\mathrm{Cu}$ dilakukan denganmenggunakan AAS (Atomic AbsorptionSpectrophotometer). Pengukuran pertumbuhan Gracilaria sp. dilakukan dengan menggunakan rumus pertumbuhan mutlak dan SGR(Effendie,1979). Specific Growth Rate (SGR) dapat dihitung menggunakan rumus menurutEffendie (1979).

Data hasil pengamatan pertumbuhan Gracilaria sp. dianalisis dengan menggunakan analisis varian untuk mengetahui besarnya pengaruh penambahan $\mathrm{Cu}$ dengan konsentrasi yang berbeda terhadap pertumbuhan Gracilariasp.
Analisis data dilakukan dengan menggunakan uji ANOVA, uji korelasi dan regresi linier sederhana.

\section{HASIL DAN PEMBAHASAN}

Hasil penelitian memperlihatkan bahwa pertumbuhan Gracilaria sp.pada setiap perlakuan memiliki hasil yang berbeda selama 28 hari masa pemeliharaan (Tabel 1). Perlakuan A (kontrol)terdapat pertambahan berat basahGracilaria sp. Hal ini memperlihatkan bahwa Gracilaria sp. pada perlakuan tersebut mengalami pertumbuhan.

Pada perlakuan B $(0,5 \mathrm{ppm})$, terjadi pertambahan berat basah pada hari ke-7, tetapi memasuki hari ke-14 sampai hari ke-28 terjadi penurunan.Perlakuan C (5 ppm) dan D (50 ppm) terjadi penurunan. Hal ini pada perlakuan tersebut tidak mengalami pertumbuhan.

Secara umum, dapat dikatakan bahwa tingkat konsentrasi danlamanyaLogamCu yang terpapardalam Gracilaria sp.akanmempengaruhi berat basah. Semakintinggi konsentrasi $\mathrm{Cu}$ yang diberikan dansemakin lama terpapar $\mathrm{Cu}$, maka berat basah Gracilaria sp. akan semakin menurun.

Menurut Hardjowigeno (2003), $\mathrm{Cu}$ merupakan mikronutrien yang esensial bagi tanaman karena walaupun diperlukan dalam jumlah relatif sedikit tetapi sangat besar peranannya. Hal ini dapat dibuktikan pada perlakuan A (kontrol) dengan konsentrasi $\mathrm{Cu} 0,04$ ppm, pada perlakuan tersebut Gracilaria sp. mengalami pertumbuhan selama 28 hari masa pemeliharaan. Pada perlakuan B $(0,5 \mathrm{ppm})$ juga mempelihatkan bahwa $\mathrm{Cu}$ sebagai mikronutrien esensial selama 7 hari, tetapi memasuki hari ke-14 sampai hari ke-28 terjadi penurunan berat basah pada Gracilaria sp. yang menandakan $\mathrm{Cu}$ sudah bersifat toksik. Menurut Munawar (2011), Cu terlibat dalam reaksi redoks $\left(\mathrm{Cu}^{2+}+\mathrm{e}^{-} \leftrightarrow \mathrm{Cu}^{+}\right)$atau transport elektron dalam fotosintesis dan respirasi, yang menghasilkan adenosin trifosfat (ATP), yang merupakan sumber energi utama untuk sintesis protein, lemak, membran sel, dan serapan hara secara aktif.

Perlakuan C (5 ppm) dan D (50 ppm) terjadi penurunan berat basah Gracilaria sp. selama 28 hari masa pemeliharaan di duga karena berlebihnya $\mathrm{Cu}$ yang masuk ke dalam tubuh Gracilaria sp.. Menurut Yulianto et al.. (2006) berlebihnya $\mathrm{Cu}$ pada tubuh suatu organisme akan mengganggu pertumbuhan atau perkembangannya bahkan akan mengakibatkan kematian.

Hasil pertumbuhan Gracilaria sp. juga diperkuat dengan hasil pertumbuhan mutlak dan laju pertumbuhan spesifik (SGR) pada tiap 
perlakuan (Tabel 2 dan 3). Hasil pertumbuhan mutlak dan laju pertumbuhan spesifik (SGR) tertinggi dicapai pada perlakuan A (kontrol) sebesar $25,34 \mathrm{~g}$ dan $0,42 \%$ per hari. Sedangkan, pada perlakuan B $(0,5 \mathrm{ppm}), \mathrm{C}(5 \mathrm{ppm})$, dan D (50 ppm) hasil memperlihatkan bahwa tidak terjadinya pertumbuhan Gracilaria sp. selama 28 hari masa pemeliharaan. Hal ini ditandai dengan adanya tanda negatif (-) pada hasil pertumbuhan mutlak dan laju pertumbuhan spesifik (SGR) Gracilaria sp,, Hasil pertumbuhan mutlak dan laju pertumbuhan spesifik (SGR) yang didapatkan pada perlakuan B $(0,5 \mathrm{ppm})$ sebesar $-80,37 \mathrm{~g}$ dan $-1,84 \%$ per hari, perlakuan C (5 ppm) sebesar 85,19 g dan $-2,02 \%$ per hari, dan perlakuan D (50 ppm) sebesar $-99,19 \mathrm{~g}$ dan $-2,47 \%$ per hari.

Proses penyerapan nutrien pada rumput laut dilakukan secara difusi melalui seluruh bagian tubuhnya. Membran sel yang merupakan bagian terluar sel setelah dinding sel bertindak sebagai pelindung isi sel yang ada dalam tubuh akan mengatur nutrien yang keluar dan masuk ke dalam sel. Sifat permeabel dari membran sel akan menyeleksi setiap zat yang dapat masuk ke dalam sel. Banyaknya nutrien yang berdifusi ke dalam sel tergantung pada konsentrasi nutrien di dalam dan di luar sel.

Pernyataan ini ditegaskan oleh Lobban dan Harrison (1994) bahwa nutrien di luar sel yang konsentrasinya lebih tinggi dibandingkan di dalam sel mengakibatkan nutrien di luar sel akan berdifusi bebas ke dalam sel sesuai kebutuhannya. Nutrien tersebut akan meningkatkan aktivitas metabolisme sel dengan cara masuk ke dalam sel sedikit demi sedikit kemudian akan mengembangkan vakuola yang ada di dalam sel. Vakuola berperan sangat penting dalam kehidupan karena mekanisme pertahanan hidup

Tabel 1. Berat Basah (g) Gracilaria sp. pada Media yang Mengandung Konsentrasi $\mathrm{Cu}$ yang Berbeda selama 28 Hari Masa Pemeliharaan $(\bar{X} \pm \mathrm{SD}, \mathrm{n}=3)$

\begin{tabular}{cccccc}
\hline \multirow{2}{*}{ Perlakuan } & \multicolumn{5}{c}{ Berat Basah $(\mathrm{g})$ pada Hari ke- } \\
\cline { 2 - 6 } & 0 & 7 & 14 & 21 & 28 \\
\hline A & $200 \pm 0,00$ & $207,35 \pm 2,68$ & $216,17 \pm 3,35$ & $221,00 \pm 2,93$ & $225,34 \pm 1,33$ \\
B & $200 \pm 0,00$ & $215,38 \pm 2,15$ & $192,75 \pm 2,40$ & $156,14 \pm 3,94$ & $119,63 \pm 2,23$ \\
C & $200 \pm 0,00$ & $150,75 \pm 4,33$ & $147,92 \pm 5,42$ & $133,28 \pm 6,75$ & $114,81 \pm 19,25$ \\
D & $200 \pm 0,00$ & $141,41 \pm 12,78$ & $139,90 \pm 11,97$ & $123,32 \pm 2,19$ & $100,81 \pm 15,24$ \\
\hline
\end{tabular}

Keterangan: $\quad \mathrm{A}=$ Kontrol; $\mathrm{B}=$ Konsentrasi $\mathrm{Cu} 0,5 \mathrm{ppm} ; \mathrm{C}=$ Konsentrasi $\mathrm{Cu} 5 \mathrm{ppm}$; D = Konsentrasi Cu 50 ppm

Tabel 2. Pertumbuhan Mutlak (g) Gracilaria sp. pada Media yang Mengandung $\mathrm{Cu}$ dengan Konsentrasi yang Berbeda selama 28 Hari Masa Pemeliharaan $(\overline{\mathrm{X}} \pm \mathrm{SD}, \mathrm{n}=3)$

\begin{tabular}{cccc}
\hline Perlakuan & Wo & Wt & G \\
\hline A & $200 \pm 0,00$ & $225,34 \pm 1,33$ & $25,34 \pm 1,33$ \\
B & $200 \pm 0,00$ & $119,63 \pm 2,23$ & $-80,37 \pm 2,23$ \\
C & $200 \pm 0,00$ & $114,81 \pm 19,25$ & $-85,19 \pm 19,25$ \\
D & $200 \pm 0,00$ & $100,81 \pm 15,24$ & $-99,19 \pm 15,24$ \\
\hline
\end{tabular}

Keterangan: $\quad \mathrm{A}=$ Kontrol; $\mathrm{B}=$ Konsentrasi $\mathrm{Cu} 0,5 \mathrm{ppm} ; \mathrm{C}=$ Konsentrasi $\mathrm{Cu} 5 \mathrm{ppm} ; \mathrm{D}=$ Konsentrasi $\mathrm{Cu} 50 \mathrm{ppm}$

Tabel 3. Laju Pertumbuhan Spesifik (SGR) Gracilaria sp. pada Media yang Mengandung $\mathrm{Cu}$ dengan Konsentrasi yang Berbeda selama 28 Hari Masa Pemeliharaan $(\overline{\mathrm{X}} \pm \mathrm{SD}, \mathrm{n}=3)$

\begin{tabular}{cccc}
\hline Perlakuan & Ln Wo & Ln Wt & SGR (\% per hari) \\
\hline A & $5,30 \pm 0,00$ & $5,42 \pm 0,01$ & $0,43 \pm 0,02$ \\
B & $5,30 \pm 0,00$ & $4,78 \pm 0,02$ & $-1,84 \pm 0,07$ \\
C & $5,30 \pm 0,00$ & $4,73 \pm 0,18$ & $-2,02 \pm 0,63$ \\
D & $5,30 \pm 0,00$ & $4,61 \pm 0,15$ & $-2,47 \pm 0,53$ \\
\hline
\end{tabular}

Keterangan: $\quad \mathrm{A}=$ Kontrol; $\mathrm{B}=$ Konsentrasi $\mathrm{Cu} 0,5 \mathrm{ppm} ; \mathrm{C}=$ Konsentrasi $\mathrm{Cu} 5 \mathrm{ppm}$; D = Konsentrasi Cu 50 ppm 
tumbuhan bergantung pada kemampuan vakuola menjaga konsentrasi zat-zat terlarut di dalamnya. Volume vakuola semakin bertambah dengan masuknya nutrien ke dalam sel yang mengakibatkan berat dari tanaman uji semakin meningkat.

Terjadinya penurunan berat basah Gracilaria sp. pada perlakuan B (0,5 ppm), C (5 ppm), dan D (50 ppm) di dugakarena Gracilaria sp. banyak menyerap $\mathrm{Cu}$ yang ada di media pemeliharaan (Tabel 4), sehingga mengganggu proses metabolisme dan menghambat pertumbuhan rumput laut tersebut. Karena $\mathrm{Cu}$ merupakan mikronutrien yang esensial bagi tubuh, tetapi apabila jumlahnya melebihi batas tolerir suatu organisme maka akan bersifat toksik.

Konsentrasi $\mathrm{Cu}$ pada kisaran yang sedikit tidak akan mengganggu pertumbuhan rumput laut, dengan adanya akumulasi $\mathrm{Cu}$ secara terus menerus dapat menghambat laju pertumbuhan rumput laut. Hal ini karena adanya kerusakan jaringan pada rumput laut akibat tingginya toksisitas $\mathrm{Cu}$ (Komarawidjaja, 20011.

Secara keseluruhan hasil analisis absorpsi Gracilaria sp. terhadap $\mathrm{Cu}$ memperlihatkan bahwa semakin besar konsentrasi $\mathrm{Cu}$ yang diberikan maka semakin besar absorpsi yang dilakukan oleh Gracilaria sp. Pernyataan ini didukung dengan analisis uji korelasi dan regresi dimana pada uji korelasi menunjukkan nilai signifikansi $(\mathrm{p}<0,05)$ di mana adanya hubungan yang signifikan antara pemberian konsentrasi terhadap absorpsi Gracilaria sp. terhadap $\mathrm{Cu}$.

Prinsip absorpsi $\mathrm{Cu}$ oleh rumput laut adalah semakin besar konsentrasi $\mathrm{Cu}$ dalam media pemeliharaan akan menyebabkan semakin besar pula $\mathrm{Cu}$ yang diserap. Hal ini disebabkan karena adanya perbedaan konsentrasi $\mathrm{Cu}$ antara dua jenis media, yaitu media dalam jaringan makroalga dan media tanam sebagai tempat pertumbuhannya. Perbedaan konsentrasi ini akan menyebabkan terjadinya perpindahan atau transfer massa $\mathrm{Cu}$ secara difusi dan osmosis, yaitu massa zat pada media dengan konsentrasi yang tinggi akan berpindah ke media dengan konsentrasi yang rendah (Santika \& Ma'ruf, 2014).

Hasil penelitian memperlihatkan bahwa Gracilaria sp. mampu mengakumulasi $\mathrm{Cu}$ melalui permukaan sel thallus dan menyebarkannya ke seluruh organ tubuhnya. Akumulasi $\mathrm{Cu}$ oleh Gracilaria sp.berlangsung melalui permukaan sel dan akan disebarkan ke seluruh organ tubuhnya sampai bagian medula (Davies, 1973 dalam Connell dan Miller, 1995). Hal ini dibuktikan dengan penurunan konsentrasi $\mathrm{Cu}$ di media pemeliharaan (Tabel 5), namun pada thallus Gracilaria sp. terjadi peningkatan konsentrasi $\mathrm{Cu}$.

Absorpsi Gracilaria sp. terhadap $\mathrm{Cu}$ mengakibatkan Gracilaria sp. memiliki gangguan secara morfologi maupun fisiologi pada thallusnya, seperti berkurangnya berat thallus, perubahan warna menjadi hijau dan mengalami pemutihan serta tekstur thallus yang tidak elastis dan mudah rapuh.

Pengamatan visual pada Gracilaria sp. memperlihatkan bahwa pada perlakuan A (kontrol) tidak terjadi perubahan warna dan tekstur thallus yang signifikan selama 28 hari masa pemeliharaan. Gracilaria sp. pada perlakuan A (kontrol) masih memiliki warna dan tekstur thallus yangcenderung sama seperti awal pemeliharaan. Hal ini di duga Gracilaria sp. mampu mentolerir keberadaan $\mathrm{Cu}$ selama 28 hari masa pemeliharaan, karena konsentrasi $\mathrm{Cu}$ pada perlakuan A (kontrol) merupakan konsentrasi yang ada pada air laut hasil filtrasi. Hal ini membuat Gracilaria sp. dapat menjalankan proses metabolisme dan perkembangan secara normal.

Pada perlakuan B $(0,5$ ppm $)$ terjadi perubahan warna pada ujung thallus dan tekstur thallus pada hari ke-21. Warna pada ujung thallus berubah dari berwarna coklat menjadi hijau, kemudian tekstur thallus menjadi non elastis dan mudah rapuh. Sedangkan pada perlakuan C (5 $\mathrm{ppm})$ dan $\mathrm{D}(50 \mathrm{ppm})$ terjadi perubahan warna thallus pada hari ke-7. Warna thallus yang awalnya berwarna coklat berubah menjadi warna hijau. Pada perlakuan C (5 ppm) perubahan warna pada ujung thallus terjadi pada hari ke-21, warna pada ujung thallus berubah dari berwarna hijau menjadi putih. Sedangkan pada perlakuan D (50 ppm) perubahan warna pada ujung thallus terjadi pada hari ke-14. Perubahan tekstur thallus(Gambar 1) pada perlakuan C (5 ppm) dan D (50 ppm) terjadi pada hari ke-21, tekstur thallus menjadi non elastis dan mudah rapuh. Pada akhir pemeliharaan, tekstur thallus pada perlakuan C (5 $\mathrm{ppm})$ dan $\mathrm{D}(50 \mathrm{ppm})$ menjadi non elastis, mudah rapuh, dan berlendir.

Menurut Yulianto et al. (2006), bahwa ketidakmampuan tanaman dalam mentoleransi konsentrasi logam berat akan mengganggu sifat tanaman seperti thallus yang menjadi non-elastis dan ujung thallus berwarna kekuningan. Hal tersebut dikarenakan adanya proses gangguan metabolisme pada Gracilaria sp. akibat akumulasi $\mathrm{Cu}$ dan lamanya waktu pemaparan yang dipengaruhi oleh mekanisme penyerapan $\mathrm{Cu}$ yang ada pada media pemeliharaan. Ketidakmampuan dalam mentolerir adanya akumulasi $\mathrm{Cu}$ 
Tabel 4. Absorpsi $\mathrm{Cu}(\mathrm{ppm})$ pada Gracilaria sp. selama 28 Hari Masa Pemeliharaan $(\bar{X} \pm \mathrm{SD}, \mathrm{n}=3)$

\begin{tabular}{cccccc}
\hline \multirow{2}{*}{ Perlakuan } & \multicolumn{5}{c}{ Absorpsi Cu $(\mathrm{ppm})$ pada Hari ke- } \\
\cline { 2 - 6 } & 0 & 7 & 14 & 21 & 28 \\
\hline $\mathrm{A}$ & $0,67 \pm 0,00$ & $1,99 \pm 0,87$ & $1,31 \pm 0,07$ & $2,58 \pm 0,91$ & $1,80 \pm 0,22$ \\
$\mathrm{~B}$ & $0,67 \pm 0,00$ & $17,45 \pm 2,07$ & $17,89 \pm 2,08$ & $19,25 \pm 3,35$ & $21,21 \pm 4,73$ \\
$\mathrm{C}$ & $0,67 \pm 0,00$ & $192,31 \pm 29,01$ & $119,91 \pm 5,42$ & $94,88 \pm 2,39$ & $79,17 \pm 14,23$ \\
$\mathrm{D}$ & $0,67 \pm 0,00$ & $312,90 \pm 38,22$ & $274,04 \pm 38,25$ & $273,19 \pm 71,14$ & $354,72 \pm 34,79$ \\
\hline Keterangan: & $\mathrm{A}=$ Kontrol; B $=$ Konsentrasi Cu 0,5 ppm; C = Konsentrasi Cu 5 ppm; D = Konsentrasi Cu 50 ppm
\end{tabular}

Tabel 5. Konsentrasi $\mathrm{Cu}(\mathrm{ppm})$ pada Media Pemeliharaan selama 28 Hari Masa Pemeliharaan $(\overline{\mathrm{X}} \pm \mathrm{SD}, \mathrm{n}=3)$

\begin{tabular}{cccccc}
\hline \multirow{2}{*}{ Perlakuan } & \multicolumn{5}{c}{ Konsentrasi Cu (ppm) pada Hari ke- } \\
\cline { 2 - 6 } & 0 & 7 & 14 & 21 & 28 \\
\hline A & $0,04 \pm 0,00$ & $0,04 \pm 0,03$ & $0,05 \pm 0,03$ & $0,03 \pm 0,01$ & $0,04 \pm 0,00$ \\
B & $0,54 \pm 0,00$ & $0,06 \pm 0,01$ & $0,11 \pm 0,03$ & $0,08 \pm 0,01$ & $0,09 \pm 0,01$ \\
C & $5,04 \pm 0,00$ & $0,31 \pm 0,01$ & $0,37 \pm 0,04$ & $0,41 \pm 0,05$ & $0,45 \pm 0,01$ \\
D & $50,04 \pm 0,00$ & $0,31 \pm 0,02$ & $1,06 \pm 0,74$ & $0,93 \pm 0,50$ & $0,51 \pm 0,10$ \\
\hline
\end{tabular}

Keterangan: $\mathrm{A}=$ Kontrol; $\mathrm{B}=$ Konsentrasi $\mathrm{Cu}$ 0,5 ppm; $\mathrm{C}=$ Konsentrasi $\mathrm{Cu} 5$ ppm; D = Konsentrasi Cu 50 ppm

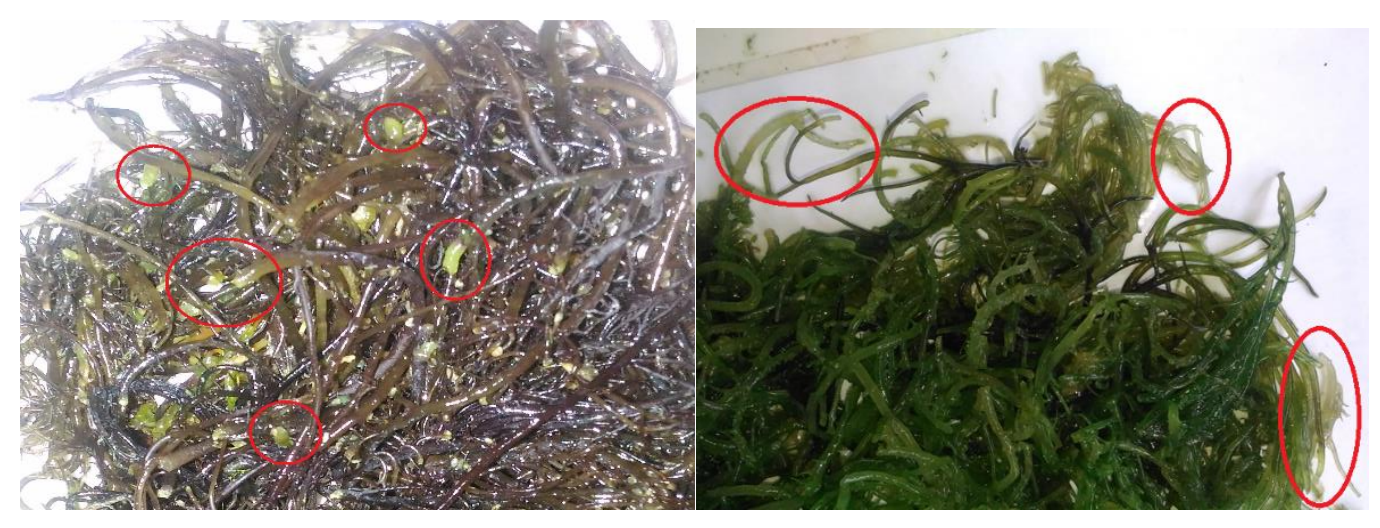

Gambar 1. Kondisi Gracilaria sp. yang Mengalami Perubahan Tekstur dan Warna pada Ujung Thallus

menyebabkan gangguan fisiologis yang mengakibatkan kerusakan organ sel tumbuhan (Dwidjoseputro, 1989),

Mekanisme pemasukan $\mathrm{Cu}$ kedalam thallus adalah melalui dinding sel. Pada dinding sel ini $\mathrm{Cu}$ diikat oleh protein dan polisakarida sehingga $\mathrm{Cu}$ dalam bentuk yang toksik $\mathrm{Cu}^{2+}$ menjadi senyawa yang non-toksik. $\mathrm{Cu}$ dalam bentuk ion bebas $\left(\mathrm{Cu}^{2+}\right)$ berpotensial menjadi toksik apabila masuk menuju bagian sel yang lebih dalam. Hal ini karena $\mathrm{Cu}$ akan berasosiasi dengan gugus senyawa penyusun enzim sehingga akan mempengaruhi aktivitas enzim yang akhirnya menyebabkan gangguan fisiologis tanaman. $\mathrm{Cu}$ dalam bentuk ion, dimana lebih dari setengahnya akan berasosiasi dan terakumulasi pada bagian dinding sel yang mempengaruhi penyerapan zatzat hara lainnya, karena dinding sel akan berubah dari semi-permeable menjadi permeable (Lobban dan Harrison, 1994).

Kualitas media pemeliharaan yang diukur selama penelitian menunjukkan rerata kisaran salinitas 23-27ppt, menurut Anggadiredja et al. (2006) salinitas optimum berkisar antara 15-30 ppt. Kisaran tersebut termasuk dalam kisaran optimal, sehingga kisaran salinitas pada media yang terukur diduga masih dapat mendukung pertumbuhan Gracilaria sp. Derajat keasaman (pH) media pemeliharaan berkisar antara 6-9, menurut Anggadiredja et al. (2006) pH optimun berkisar antara 6-9, sehingga kisaran tersebut termasuk dalam kisaran yang optimal. Kisaran suhu pada media pemeliharaan berkisar antara 24$27,5^{\circ} \mathrm{C}$, menurut Anggadiredja et al. (2006) suhu optimum berkisar antara $20-28^{\circ} \mathrm{C}$, sehingga kisaran suhu yang terukur masih termasuk dalam 
kisaran yang optimal walaupun setiap hari mengalami perubahan.

\section{KESIMPULAN}

Nilai konsentrasi $\mathrm{Cu}$ yang diberikan pada Gracilaria sp. memberikan efek yang berbeda terhadap pertumbuhannya. Pada perlakuan A (kontrol) dengan konsentrasi 0,04 ppm, Gracilaria sp. mengalami pertumbuhan selama 28 hari masa pemeliharaan. Sedangkan pada perlakuan B dengan konsentrasi 0,5 ppm, Gracilaria sp. hanya mengalami pertumbuhan selama 7 hari. Sementara pada perlakuan C dan D dengan konsentrasi $5 \mathrm{ppm}$ dan $50 \mathrm{ppm}$ tidak terjadi pertumbuhan Gracilaria sp. selama 28 hari masa pemeliharaan.Pertumbuhan Gracilaria sp. pada media yang mengandung konsentrasi $\mathrm{Cu}$ yang berbeda memberikan pengaruh nyata terhadap pertumbuhan rumput laut tersebut $(\mathrm{p}<$ 0,05 ). Semakin tinggi konsentrasi $\mathrm{Cu}$ yang diberikan maka pertumbuhan Gracilaria sp. akan semakin rendah.Kemampuan absorpsi Gracilaria sp. pada media yang mengandung konsentrasi $\mathrm{Cu}$ yang berbeda memperlihatkan semakin tinggi konsentrasi $\mathrm{Cu}$ yang diberikan maka kemampuan absorpsi $\mathrm{Cu}$ pada Gracilaria sp. akan semakin tinggi.

\section{DAFTAR PUSTAKA}

Akmal, Ilham, Suaib, M., Irwan \& Arifin, M. 2008. Produksi Spora dalam Upaya Penyediaan Bibit Rumput Laut Gracilaria verrucosa. Indonesian Aquaculture, Yogyakarta.

Alamsjah, M.A., Hirao, S., Ishibashi, F., Oda, T., \& Fujita, Y. 2008. Algicidal activity of polyunsaturated fatty acids derived from Ulva fasciata and U. pertusa (Ulvaceae, Chlorophyta) on phytoplankton. Journal of Applied Phycology, 20(5):713-720.

Anggadiredja, J.T., Zatnika,A., Purwoto,H.,\& S. Istini. 2006. Rumput Laut. Penebar Swadaya, Jakarta, 148 hlm.
2008. RumputLaut; Pembudidayaan, Pengolahan, dan Pemasaran Komoditas Perikanan Potensial. Penebar Swadaya, Jakarta. $147 \mathrm{hlm}$.

Budiyani, F.B., Suwartimah, K., \& Sunaryo, S. 2012. Pengaruh Penambahan Nitrogen dengan Konsentrasi yang Berbeda terhadap Laju Pertumbuhan Rumput Laut Caulerpa racemosa var. uvifera. Journal of Marine Research, 1(1):10-18.

Connel, D.W., \& Miller, G.J. 1995. Kimia dan ekotoksikologi pencemaran. Penerjemah: Koestoer, Y. Judul asli: Chemistry and Ecotoxicology Of Pollution. Tahun.

Effendie, M.I. 1979. Metode Biologi Perikanan. Yayasan Dewi Sri Bogor, Bogor, $112 \mathrm{hlm}$.

Hardjowigeno, S. 2003. Ilmu Tanah. Akademika Pressindo, Jakarta.

Komarawidjaja, W. 2011. Rumput Laut Gracilaria sp. Sebagai fitoremedian bahan organic perairan tambak budidaya. Jurnal Teknologi Lingkungan, 6(2):410-415.

Lobban, C.S., \& Harrison, P.J. 1994. Seaweed Ecology and Physiology. Cambridges University Press, USA, 366 .

Santika, L.G., \& Ma'ruf, W.F. 2014. Karakteristik Agar Rumput Laut Gracilaria Verrucosa Budidaya Tambak Dengan Perlakuan Konsentrasi Alkali Pada Umur Panen Yang Berbeda. Jurnal Pengolahan dan Bioteknologi Hasil Perikanan, 3(4):98-105.

Prihartono, E., Juansyah, R. \& Usnie, A. 2010. Mengatasi Permasalahan Budidaya Lele Dumbo. Penebar Swadaya, Jakarta.

Sitompul, S.M. 2015 Nutrisi Tanaman: Pengenalan Nutrisi Tanaman. UB Press: Malang.

Yulianto, B., Ario, R., \& Agung, T. 2006.Daya Serap Rumput Laut (Gracilariasp) Terhadap LogamBerat Tembaga $(\mathrm{Cu})$ Sebagai Biofilter. Ilmu Kelautan: Indonesian Journal of Marine Sciences, 11(2):72-78. 